\title{
Detecting age-structured effects in growth performance of coral reef fish juveniles
}

\author{
C. Mellin ${ }^{1,2, *}$, R. Galzin ${ }^{3}$, D. Ponton ${ }^{1}$, L. Vigliola ${ }^{4}$ \\ ${ }^{1}$ IRD, UR 128, BP A5, 98848 Nouméa Cedex, New Caledonia \\ ${ }^{2}$ Research Institute for Climate Change and Sustainability, School of Earth and Environmental Sciences, \\ University of Adelaide, South Australia 5005, Australia \\ ${ }^{3}$ UMR 5244 CNRS-EPHE-UPVD, Université de Perpignan, 66860 Perpignan Cedex, France \\ ${ }^{4}$ IRD, UR 070, BP 70, 29280 Plouzané, France
}

\begin{abstract}
The growth performance of coral reef fish juveniles collected in different habitats is often used as a proxy for habitat quality for juveniles. However, back-calculated growth trajectories of juveniles may be age-structured, for instance, because of potential differences in initial offspring size and/or quality or size-selective mortality. A novel approach is proposed to isolate growth performance of coral reef fish juveniles from potential age-based factors. Juveniles of Chromis viridis (Pomacentridae), Lethrinus genivittatus (Lethrinidae) and Siganus fuscescens (Siganidae) were collected from waters around inshore and offshore islets in a coral reef lagoon. Individual growth trajectories were back-calculated from otolith increments and compared with repeated-measures generalised linear models (RM-GLMs). Settlement marks in otoliths were used to differentiate larval and juvenile growth trajectories for each individual. For the 3 species, fish from around the offshore islet presented significantly larger size-at-age during their larval stage than those from from around the inshore islet. Juveniles of L. genivittatus and S. fuscescens from around the offshore islet remained larger than inshore juveniles at the same age, while growth curves of $C$. viridis from the 2 islets crossed at settlement so that inshore fish were larger as juveniles than offshore individuals. RM-GLMs revealed that the growth trajectory was significantly age-structured for $C$. viridis only. These results suggest that post-settlement age may be used as a covariate in comparative analyses of larval growth in order to isolate growth performance from potential age-based factors.
\end{abstract}

KEY WORDS: Back-calculation - Body size - Generalised linear models · Natural selection · Repeated measures $\cdot$ Settlement

Resale or republication not permitted without written consent of the publisher

\section{INTRODUCTION}

Early life history stages in fish are generally characterized by high mortality, mostly due to predation, starvation or sublethal factors (e.g. Houde 1987). This high mortality is generally not random. According to the growth-mortality hypothesis, the probability of survival may be influenced by individual size and growth performance (Cowen \& Sponaugle 1997). This hypothesis relies on the idea that individuals with a larger size-at-age show improved foraging ability that further results in increased growth rate, shorter life history stage duration and/or reduced vulnerability to predation (Cowan et al. 1997). For instance, field evidence has demonstrated growth-selective mortality due to predation in larval Atlantic cod (Meekan \& Fortier 1996), Japanese anchovy (Takasuka et al. 2003) and Mediterranean labrids (Raventos \& Macpherson 2005). In coral reef fish, mortality is mostly due to predation and typically leads to survival rates of $<1 \%$ at the end of the juvenile phase (Leis 1991, Doherty et al. 2004). Evidence has revealed that the growth-mortality hypothesis also applies to coral reef fish, with reports of size-based selective mortality during both the planktonic larval (Gagliano \& McCormick 2007a) and the benthic juvenile (Searcy \& Sponaugle 2001, Vigliola et al. 2007) stages of fishes. Because individual growth strongly determines survival and, hence, re- 
cruitment success, determining the factors that influence growth performance is a key challenge for both science and management.

For coral reef fish, individual growth performance may be influenced by several factors, including age, initial offspring size or quality, environmental conditions experienced during early life history stages or growth-selective mortality. Variations in larval and juvenile growth rates and their effect on subsequent survival can originate from genetic (Vigliola et al. 2007) and non-genetic parental contributions (Jones \& McCormick 2002). Growth rates also depend on environmental factors such as food availability, water temperature and habitat quality (Cowen \& Sponaugle 1997). Because growth is a cumulative process, larger individuals that experience a higher growth rate as larvae are often larger and faster-growing as juveniles (e.g. Cowan et al. 1997, Vigliola \& Meekan 2002). This explains why post-settlement selection for fast-growing juveniles also removes individuals that were slowgrowing pelagic larvae from benthic populations (Vigliola \& Meekan 2002, Vigliola et al. 2007). Growthselective mortality may also drive other early life history traits that are linked to larval growth, including pelagic larval duration (PLD; Denit \& Sponaugle 2004) or size at settlement (McCormick 1994). These studies altogether suggest that both spatial and temporal structures may exist in the distribution of early life history traits of coral reef fish and play a key role in survival and the replenishment of adult populations, thus bridging the gap between early life history traits and the concept of essential juvenile habitats (Dahlgren et al. 2006).

Identifying habitats and environmental conditions that favor high growth performance for different species requires data sets on both larval and juvenile attributes for individuals collected at different sites. For this purpose, individual growth trajectories can be back-calculated from hatching to capture through the analysis of otolith daily growth increments (e.g. Vigliola \& Meekan in press). The presence of settlement marks in otoliths (Wilson \& McCormick 1999, Vigliola et al. 2000) also enables back-calculation of size and age at the time of settlement. However, a major issue arising when comparing back-calculated information for individuals collected as juveniles at different sites is that the information is based on survivors only, which may mask the potential effect of age-based factors on growth performance. For instance, a fast juvenile growth may reflect a response to favourable environmental conditions, difference in offspring size and quality or post-settlement selective predation against individuals that were smaller or grew slower as larvae (Robert et al. 2007, Vigliola et al. 2007). Therefore, prior to using growth as a proxy for comparing the quality of habitats, one must assess whether the size distribution differs in shape between habitats, which may suggest different mortality schedules, or whether populations from different habitats have different age distributions, which would illustrate the potential for temporal drivers of growth performance.

The present study examined the effect of habitat on the growth trajectory, size at settlement and PLD of 3 coral reef fish species. The study species (a damselfish, an emperor and a rabbitfish) have contrasting ecologies and early life history traits were compared between individuals from around inshore vs offshore islets. As in previous studies assessing spatial variations in fish growth, growth trajectories were determined from otolith analyses and compared among sites, but for the first time we accounted for the potential effect of age in structuring juvenile growth performance.

\section{MATERIALS AND METHODS}

Field sampling. The present study was conducted in New Caledonia (southwest Pacific, $166^{\circ} \mathrm{E}, 22^{\circ} \mathrm{S}$ ). The barrier reef lies between 1 and $65 \mathrm{~km}$ from the main island, enclosing a lagoon that covers a total area of approximately $24000 \mathrm{~km}^{2}$ and which provides a wide shelf with a high diversity of biotopes (Andréfouët \& Torres-Pulliza 2004). Fish from 2 sites within the southwestern part of the lagoon, from waters around Canard and Larégnère Islets $(1.2$ and $13 \mathrm{~km}$ from the main island, respectively; Fig. 1), were sampled. Located near a pass, Larégnère Islet is an offshore islet submitted to oceanic influence, whereas Canard Islet is submitted to the terrigeneous influence of the main island (Pinazo et al. 2004).

The study species comprised Chromis viridis (Pomacentridae), Lethrinus genivitattus (Lethrinidae) and Siganus fuscescens (Siganidae; Table 1). Juveniles of Chromis viridis were caught from 1 to 2 March 2006 by 2 divers using clove oil and a hand net within aggregations observed on the fringing reef of each islet. Juveniles of Lethrinus genivitattus and Siganus fuscescens were caught from 23 to 24 November and 7 to 8 December 2005, respectively, by 2 divers dragging a $10 \times$ $1.20 \mathrm{~m}$ (length $\times$ height, $4 \mathrm{~mm}$ mesh-size) underwater seine in seagrass beds around each islet. Depending on the number of fish present, either 1 or 2 stations randomly selected around each islet were visited (Fig. 1). Given the relatively short distances between stations over which juvenile fish are likely to move (C. Mellin unpubl.) and little difference in environmental conditions between stations compared with differences between islets (e.g. Pinazo et al. 2004), fish from the same islet were pooled together. Upon collection, all individuals were anaesthetized in a benzocaine solution and immediately preserved in $95 \%$ methylated alcohol. 


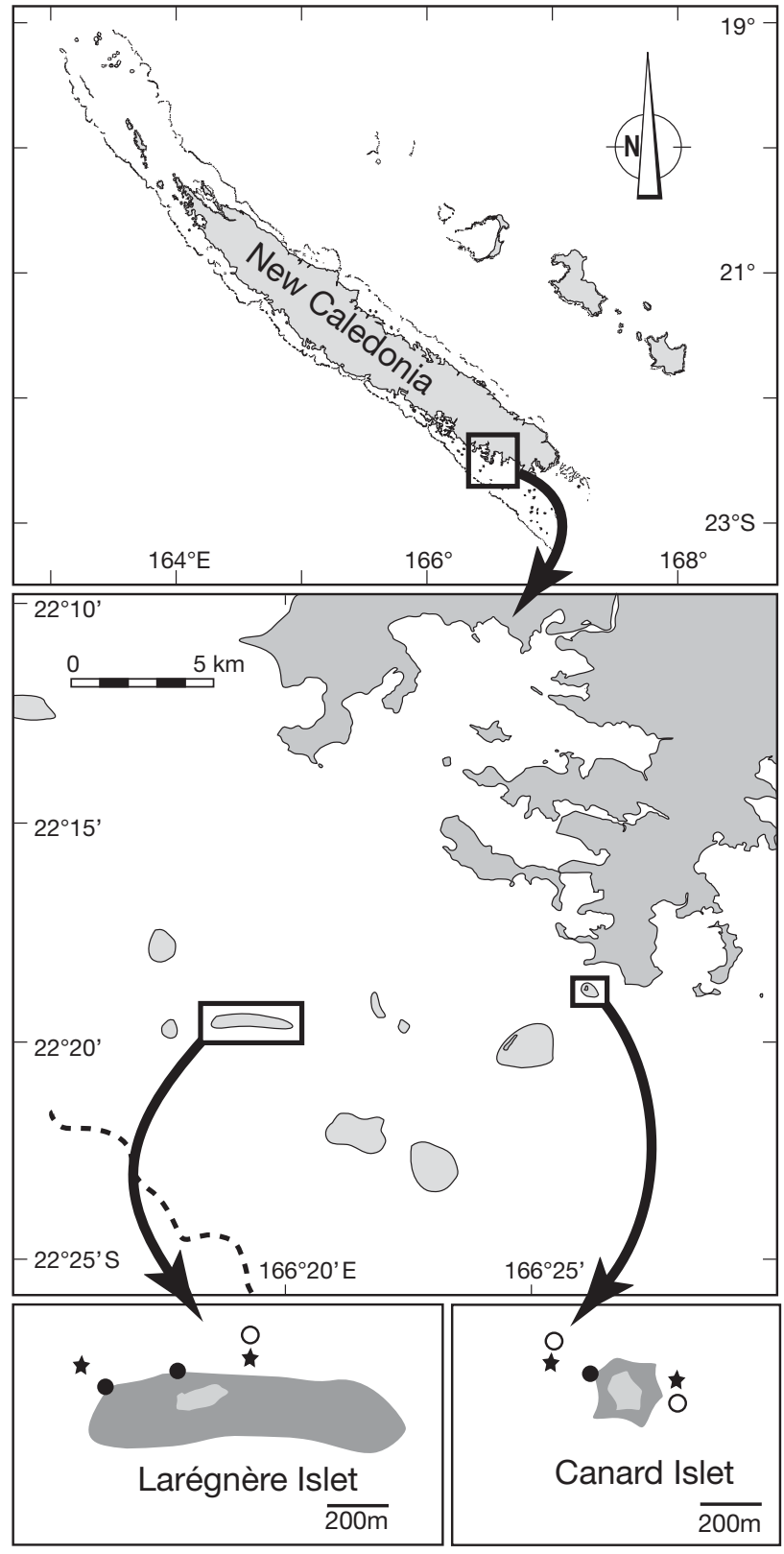

Fig. 1. Positions of the stations where Chromis viridis (๑), Lethrinus genivittatus ( $\star$ ) and Siganus fuscescens (O) were collected around Larégnère and Canard Islets in the southwest lagoon of New Caledonia. For each islet, light grey represents the emerged area and dark grey the reef flat. The dashed line in the center panel represents the barrier reef, interrupted by the Dumbéa Pass on the southeastern side of Larégnère Islet

In the laboratory, all juveniles were measured to the nearest $1 \mathrm{~mm}$ standard length (SL) using an electronic calliper. All collected Chromis viridis $(\mathrm{n}=45)$ and Lethrinus genivittatus $(\mathrm{n}=40)$ were selected for otolith analyses. Because the sample size was much larger for Siganus fuscescens $(\mathrm{n}=235), 47$ individuals were subsampled for otolith analysis proportionally to their abundance in each $1 \mathrm{~mm}$ size class within collections from each islet (see Table 2).

Otolith analysis. Based on preliminary examinations that indicated which otoliths were the most readable, we used sagittae for Siganus fuscescens and lapilli for Chromis viridis and Lethrinus genivitattus. For each selected individual, 1 otolith was embedded in thermoplastic glue Crystal Bond ${ }^{\mathrm{TM}}$ over the edge of a glass slide, the core remaining inside the edge of the glass. The protruding portion was ground off using 9, 3 and $1 \mu \mathrm{m}$ grade lapping film. The remaining portion of the otolith was then glued upright on a new glass slide and then ground with the same series of lapping films to produce a thin transverse section containing the core. Poor otolith preparation resulted in unreadable otoliths for 15 C. viridis, 5 L. genivittatus and 6 S. fuscescens. Otolith sections of the remaining 106 fish were observed using a compound microscope under transmitted light at $400 \times$ magnification.

Digital pictures of each section were captured using a charge-coupled device camera connected to a computer. Age at capture was defined as the number of increments from the core to the outer edge of the otolith, assuming that 1 increment was deposited each

Table 1. Chromis viridis, Lethrinus genivittatus and Siganus fuscescens. Adult diet, main habitat, schooling behaviour, spawning mode and larval length at hatching for C. viridis (Pomacentridae), L. genivittatus (Lethrinidae) and S. fuscescens (Siganidae)

\begin{tabular}{|c|c|c|c|c|c|}
\hline Species & Diet & Habitat & Schooling & Spawning mode & $\begin{array}{l}\text { Larval length } \\
\text { at hatching }(\mathrm{mm})\end{array}$ \\
\hline C. viridis & Planktivorous $^{1}$ & Coral colonies $^{2}$ & $\begin{array}{l}\text { Form large and } \\
\text { sedentary schools }{ }^{2}\end{array}$ & Benthic $^{1}$ & $2.1-4.0^{6}$ \\
\hline L. genivittatus & Carnivorous $^{1}$ & Shallow seagrass beds ${ }^{2}$ & $\begin{array}{l}\text { Form large, loose } \\
\text { and mobile schools }{ }^{3}\end{array}$ & Pelagic $^{1}$ & $1.3-1.8^{6}$ \\
\hline S. fuscescens & Herbivorous $^{1}$ & $\begin{array}{c}\text { Shallow seagrass } \\
\text { and macroalgal beds }\end{array}$ & $\begin{array}{l}\text { Form large, compact } \\
\text { and mobile schools }{ }^{4,5}\end{array}$ & Benthic $^{4}$ & $2.0^{6}$ \\
\hline
\end{tabular}


day and that the first increment was formed at hatching, as is the case in most species, including coral reef fish species (Pitcher 1988, Campana 1990). Each fish was aged twice at a $10 \mathrm{~d}$ interval by the same person (C. Mellin). If age estimates differed by $>5 \%$, the fish was not kept for analysis. This occurred for 9 individuals so that our final sample for data analysis comprised 27 Chromis viridis, 29 Lethrinus genivittatus and 41 Siganus fuscescens (see Table 2).

For each remaining fish, the distance of each increment to the core was measured using ImageJ software v.1.34 (http://rsbweb.nih.gov/ij/). All 3 study species displayed a type Ia settlement mark characterized by a sharp decrease in increment width at the time of settlement (Wilson \& McCormick 1999). The PLD was defined as the number of increments between the core of the otolith and the settlement mark.

Data analysis. Both experimental and theoretical evidence indicate that using back-calculation models of fish size from otoliths provides more reliable proxies of fish size at age than otolith radius (Wilson et al. 2008, Vigliola \& Meekan in press). The size of each fish between hatching and capture was back-calculated from otoliths using allometric (modified Fry; Vigliola et al. 2000) or linear (biological intercept; Campana 1990) back-calculation models, depending on the shape (i.e. allometric or linear) of the relationship between otolith radius and SL (Vigliola et al. 2000). Both models include a biologically determined intercept, i.e. the mean size of the otolith $\left(\mathrm{R}_{0 \mathrm{p}}\right)$ and the larvae $\left(\mathrm{L}_{0 \mathrm{p}}\right)$ at hatching to minimize growth effects (Campana 1990). $R_{0 \mathrm{p}}$ was estimated for each species by averaging the core radii of all examined otoliths. $\mathrm{L}_{0 \mathrm{p}}$ was estimated from sizes at hatching reported for the species in the Indo-Pacific region (Leis \& Carson-Ewart 2001) at $3 \mathrm{~mm}$ for Chromis viridis, $1.5 \mathrm{~mm}$ for Lethrinus genivittatus and $2 \mathrm{~mm}$ for Siganus fuscescens.

Repeated-measures generalised linear models (RM-GLMs) were used to compare back-calculated growth trajectories of fish collected around Canard and Larégnère Islets. Age was entered in the models as an intrasubject factor repeated at $5 \mathrm{~d}$ intervals before settlement, at settlement and at $5 \mathrm{~d}$ intervals after settlement. Site was entered as an inter-subject factor in order to test for differences in size-atage between islets. Post-settlement age (PSage) was entered as a covariate in order to evaluate its effect on growth trajectory. For each species, all possible RM-GLMs with terms age $\times$ site, age $\times$ PSage and age $\times$ site $\times$ PSage were fitted to the data. The most parsimonious model was retained based on minimal Akaike's information criterion (AIC; Sakamoto et al. 1986). For the 3 study species, Mauchly's test validated the assumption of sphericity in the variance/covariance matrix of the dependent variable (i.e. size-at-age; $\mathrm{p}<0.001$ ), which guarantees the validity of $F$-statistics even with small sample sizes (Cornell et al. 1992). All statistical analyses were performed using SPSS v.12.0.1.

\section{RESULTS}

A total of 45 Chromis viridis (9-19 mm SL), 40 Lethrinus genivittatus (19-47 mm SL) and 235 Siganus fuscescens (23-30 mm SL) (Table 2) were collected. For each species, length distributions were unimodal (Table 3) and did not differ significantly between islets (Kolmogorov-Smirnov test, $\mathrm{p}>0.05$ ). Age-at-capture ranged between 37 and $71 \mathrm{~d}$ for $C$. viridis, 30 and $75 \mathrm{~d}$ for L. genivittatus and 19 and $27 \mathrm{~d}$ for $S$. fuscescens (Table 3). Ranges in post-settlement age (i.e. number of days between settlement and capture) were 13 to 48,2 to 47 and 1 to $5 \mathrm{~d}$ for the 3 species, respectively. Settlement dates were distributed within approximately 1 mo for C. viridis, 1.5 mo for L. genivittatus and $1 \mathrm{wk}$

Table 2. Chromis viridis, Lethrinus genivittatus and Siganus fuscescens. Number of fish collected around Canard and Larégnère Islets, New Caledonia, subsampled for otolith preparation and kept for statistical analyses, with their mean, minimum and maximum standard length ( $\mathrm{mm})$

\begin{tabular}{|c|c|c|c|c|c|c|}
\hline \multirow[t]{2}{*}{ Species } & \multirow[t]{2}{*}{ Islet } & & \multirow[t]{2}{*}{$\mathrm{N}$} & \multicolumn{3}{|c|}{ Standard length (mm) } \\
\hline & & & & Mean & Min. & Max. \\
\hline \multirow[t]{6}{*}{ C. viridis } & \multirow[t]{3}{*}{ Canard } & Collected & 12 & 16.9 & 15 & 19 \\
\hline & & Subsampled & 12 & 16.9 & 15 & 19 \\
\hline & & Analyzed & 10 & 16.5 & 15 & 19 \\
\hline & \multirow[t]{3}{*}{ Larégnère } & Collected & 33 & 15.5 & 9 & 18 \\
\hline & & Subsampled & 33 & 15.5 & 9 & 18 \\
\hline & & Analyzed & 17 & 14.1 & 10 & 18 \\
\hline \multirow[t]{6}{*}{ L. genivittatus } & \multirow[t]{3}{*}{ Canard } & Collected & 20 & 27.6 & 19 & 46 \\
\hline & & Subsampled & 20 & 27.6 & 19 & 46 \\
\hline & & Analyzed & 16 & 28.2 & 21 & 46 \\
\hline & \multirow[t]{3}{*}{ Larégnère } & Collected & 20 & 34.1 & 21 & 47 \\
\hline & & Subsampled & 20 & 34.1 & 21 & 47 \\
\hline & & Analyzed & 13 & 35.5 & 21 & 47 \\
\hline \multirow[t]{6}{*}{ S. fuscescens } & \multirow[t]{3}{*}{ Canard } & Collected & 156 & 26.0 & 24 & 30 \\
\hline & & Subsampled & 26 & 26.0 & 24 & 30 \\
\hline & & Analyzed & 23 & 26.6 & 24 & 29 \\
\hline & \multirow[t]{3}{*}{ Larégnère } & Collected & 79 & 25.6 & 23 & 29 \\
\hline & & Subsampled & 21 & 25.6 & 23 & 29 \\
\hline & & Analyzed & 18 & 25.6 & 23 & 29 \\
\hline
\end{tabular}


Table 3. Chomis viridis, Lethrinus genivittatus and Siganus fuscescens. Age at capture (d), hatching dates, pelagic larval duration (PLD; d), size at settlement (mm) and settlement dates of C. viridis, L. genivittatus and S. fuscescens collected at Canard and Larégnère Islets, New Caledonia. N: number of interpreted otoliths. Dates are given as dd/mm/yy. Bold numbers indicate significant differences between islets (repeated-measures generalised linear models; $\mathrm{p}<0.01$ )

\begin{tabular}{|c|c|c|c|c|c|c|c|}
\hline Species & Islet & $\mathrm{N}$ & $\begin{array}{l}\text { Age at } \\
\text { capture }\end{array}$ & $\begin{array}{l}\text { Hatching } \\
\text { date }\end{array}$ & $\begin{array}{l}\text { Mean PLD } \\
\text { (range) }\end{array}$ & $\begin{array}{l}\text { Size at settlement } \\
\text { (range) }\end{array}$ & $\begin{array}{l}\text { Settlement } \\
\text { date }\end{array}$ \\
\hline \multirow[t]{3}{*}{ C. viridis } & Both & 27 & $37-71$ & 20/12/05-24/01/06 & $20.5(17-25)$ & $7.9(6.0-9.9)$ & $12 / 01 / 06-17 / 02 / 06$ \\
\hline & Canard & 10 & $37-61$ & $31 / 12 / 05-24 / 01 / 06$ & $21.4(17-25)$ & $8.1(6.0-9.9)$ & $19 / 01 / 06-17 / 02 / 06$ \\
\hline & Larégnère & 17 & $37-71$ & $20 / 12 / 05-23 / 01 / 06$ & $19.9(17-25)$ & $7.8(6.3-9.2)$ & $12 / 01 / 06-10 / 02 / 06$ \\
\hline \multirow[t]{3}{*}{ L. genivittatus } & Both & 29 & $30-75$ & 09/09/05-25/10/05 & $27.6(24-31)$ & $16.5(8.4-25.8)$ & 07/10/05-22/11/05 \\
\hline & Canard & 16 & $30-75$ & 09/09/05-24/10/05 & $27.8(24-31)$ & $15.0(8.4-19.0)$ & 07/10/05-18/11/05 \\
\hline & Larégnère & 13 & $30-67$ & $18 / 09 / 05-25 / 10 / 05$ & $27.5(24-31)$ & $18.2(13.7-25.8)$ & $14 / 10 / 05-22 / 11 / 05$ \\
\hline \multirow[t]{3}{*}{ S. fuscescens } & Both & 41 & $19-27$ & 11/11/05-19/11/05 & $19.2(17-23)$ & $23.1(19.9-26.9)$ & 29/11/05-07/12/05 \\
\hline & Canard & 23 & $21-27$ & $11 / 11 / 05-17 / 11 / 05$ & $19.9(17-23)$ & $23.3(20.2-26.9)$ & $03 / 12 / 05-07 / 12 / 05$ \\
\hline & Larégnère & 18 & $19-26$ & 11/11/05-19/11/05 & $18.3(17-20)$ & 22.9 (19.9-26.6) & 29/11/05-06/12/05 \\
\hline
\end{tabular}

for $S$. fuscescens. Pelagic larval durations (mean $\pm \mathrm{SE}$ ) were estimated at $20.5 \pm 0.5 \mathrm{~d}$ for $C$. viridis, $27.6 \pm 0.4 \mathrm{~d}$ for L. genivittatus and $19.2 \pm 0.2 \mathrm{~d}$ for $S$. fuscescens.

For Chromis viridis and Lethrinus genivittatus, the relationship between fish length and otolith radius was allometric ( $t$-test, $\mathrm{p}<0.05)$ and highly significant $(C$. viridis, $\mathrm{p}<0.001, \mathrm{R}^{2}=0.78 ;$ L. genivittatus, $\mathrm{p}<$ $0.001, R^{2}=0.84$; Table 4), implying that the modified Fry model was most appropriate for length back-calculation. For Siganus fuscescens, the narrow range of SL did not allow testing for allometry. A linear relationship between fish length and otolith radius was assumed for this species $\left(p=0.001, R^{2}=0.29 ;\right.$ Table 4$)$ and the linear biological intercept model used for length back-calculation.

The most parsimonious RM-GLMs (i.e. smallest AIC) contained the full factorial design for Chromis viridis and only the islet factor for the 2 other species (Table 5). For the 3 species, RMGLMs showed that back-calculated growth trajectories differed significantly between islets. Prior to settlement, spatial patterns in size-at-age were consistent for the 3 species, with fish collected at Larégnère Islet being significantly larger as larvae than those caught at Canard Islet (Fig. 2). Settlement occurred around both islets at a similar age for both $C$. viridis and Lethrinus genivittatus, whereas settlers were significantly younger at Larégnère Islet than at Canard Islet for Siganus fuscescens (Table 3, Fig. 2). Size at settlement significantly differed between islets for L. genivittatus only, settlers being larger at Larégnère Islet than at Canard Islet. After settlement, juveniles remained larger at Larégnère Islet for both $L$. genivittatus and $S$. fuscescens (Fig. 2). While juvenile growth trajectories were relatively parallel offshore and inshore for both

Table 4. Allometric $\left(\mathrm{L}=\mathrm{L}_{0 \mathrm{p}}-\mathrm{bR}_{0 \mathrm{p}}{ }^{\mathrm{c}}+\mathrm{bR}^{\mathrm{c}}\right)$ and linear $\left(\mathrm{L}=\mathrm{L}_{0 \mathrm{p}}-\mathrm{bR}_{0 \mathrm{p}}+\mathrm{bR}\right)$ regression relationships (see Vigliola et al. 2000) between fish length (L) and otolith radius (R) for Chromis viridis, Lethrinus genivittatus and Siganus fuscescens. Number of individuals examined $(\mathrm{N})$, mean otolith radius $\left(\mathrm{R}_{0 \mathrm{p}}, \mu \mathrm{m}\right)$ and fish length at hatching $\left(\mathrm{L}_{0 \mathrm{p}}, \mathrm{mm} \mathrm{SL}\right)$ are given for each species. NA: not applicable

\begin{tabular}{|lcccccc|}
\hline Species & $\mathrm{N}$ & $\mathrm{R}_{0 \mathrm{p}}(\mu \mathrm{m})$ & $\mathrm{L}_{0 \mathrm{p}}(\mathrm{mm})$ & Model & $\mathrm{p}$ & $\mathrm{R}^{2}$ \\
\hline C. viridis & 27 & $3.8 \pm 1.3$ & 3.0 & Allometric & $<0.001$ & 0.78 \\
& & & & Linear & $<0.001$ & 0.64 \\
L. genivittatus & 29 & $3.3 \pm 0.7$ & 1.5 & Allometry & $<0.001$ & 0.84 \\
& & & & Linear & $<0.001$ & 0.73 \\
S. fuscescens & 41 & $3.1 \pm 0.7$ & 2.0 & Allometric & NA & NA \\
& & & & Linear & 0.001 & 0.29 \\
\hline
\end{tabular}

Table 5. Summary of results for the most parsimonious (i.e. smallest Akaike's information criterion [AIC]) repeated-measures generalised linear model (RMGLM) analyses of back-calculated size-at-age trajectories for Chromis viridis, Lethrinus genivittatus and Siganus fuscescens collected around Canard and Larégnère Islets, New Caledonia. PSage: post-settlement age

\begin{tabular}{|lccccccc|}
\hline Species & $\mathrm{R}^{2}$ & AIC & Source & df & Wilk's $\lambda$ & $F$ & $\mathrm{p}$ \\
\hline C. viridis & 0.87 & 10.55 & $\begin{array}{c}\text { age } \times \text { islet } \\
\text { age } \times \text { PSage }\end{array}$ & 6 & 6.20 & 12.12 & $<0.001$ \\
& & & & 0.48 & 3.30 & 0.023 \\
& & & age $\times$ PSage $\times$ islet & 6 & 0.33 & 6.09 & 0.001 \\
L. genivittatus & 0.98 & 60.00 & age $\times$ islet & 7 & 0.20 & 9.15 & $<0.001$ \\
S. fuscescens & 0.98 & 101.65 & age $\times$ islet & 6 & 0.63 & 2.83 & 0.027 \\
\hline
\end{tabular}



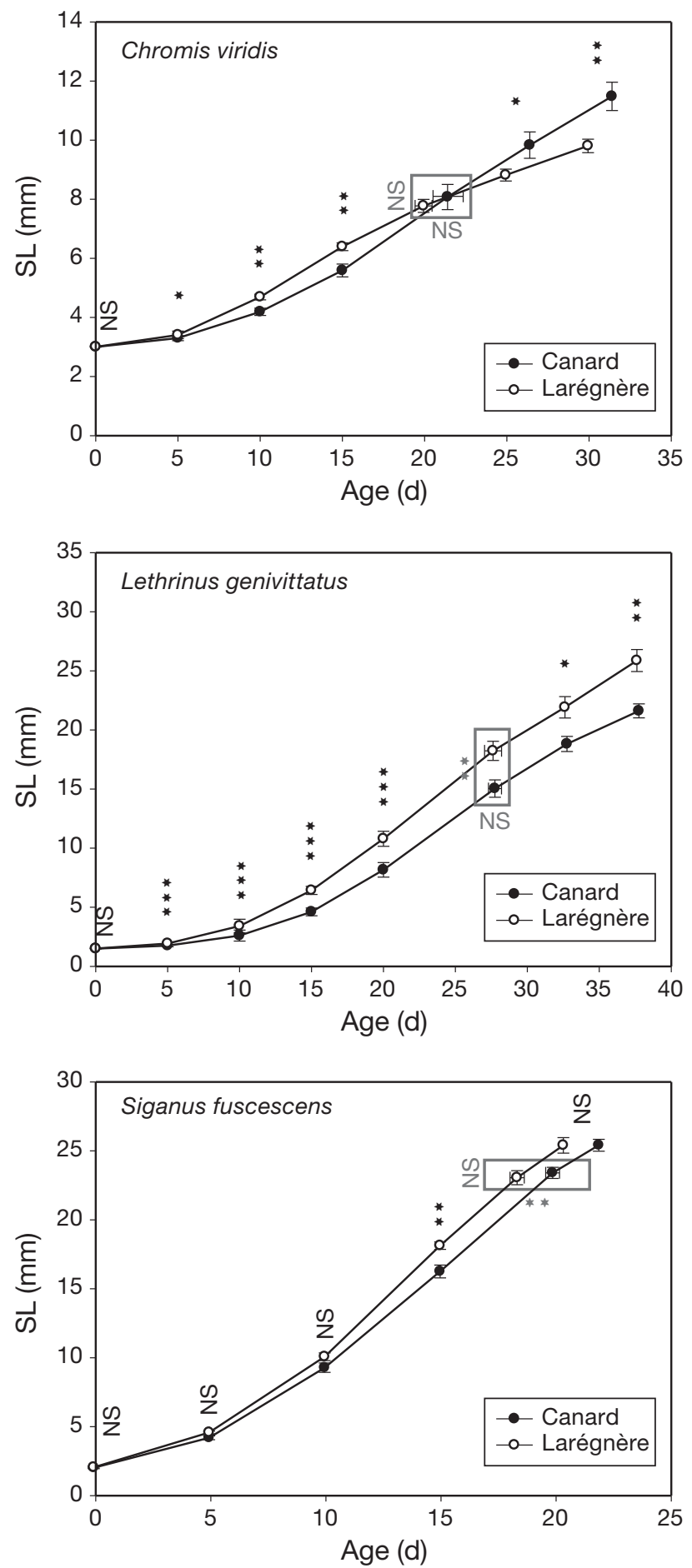

Fig. 2. Chromis viridis, Lethrinus genivittatus and Siganus fuscescens. Mean and SE (error bars) of back-calculated sizeat-age (standard length [SL], mm) of $C$. viridis, $L$. genivittatus and $S$. fuscescens collected around Canard and Larégnère Islets. Differences in back-calculated sizes between sites were tested every $5 \mathrm{~d}$ from hatching before settlement and every $5 \mathrm{~d}$ after settlement (using repeated-measures generalised linear models). The settlement period is outlined (grey box) and the significance of differences in age at settlement is indicated next to the box. ${ }^{* * *} \mathrm{p}<0.001 ;{ }^{* *} \mathrm{p}<0.01 ;{ }^{*} \mathrm{p}<0.05 ;$ NS: $\mathrm{p} \geq 0.05$
L. genivittatus and S. fuscescens, this was not the case for $C$. viridis. For this species, growth curves crossed at settlement so that fish settled at about the same size at both islets and individuals collected offshore were smaller as juveniles.

The most parsimonious RM-GLM for Chromis viridis included a significant effect of post-settlement age (Table 5). This result indicated that the back-calculated growth trajectory of this species was influenced by the age at which individuals were caught in the benthic habitat. Significant age $\times$ islet $\times$ PSage interaction in the model further revealed that the effect of postsettlement age was different for the 2 islets (Table 5), being positive for Larégnère Islet and negative for Canard Islet. Indeed, predictions of the RM-GLM for different values of PSage showed that post-settlement growth strongly decreased for Canard Islet and slightly increased for Larégnère Islet when PSage increased from 10 to $40 \mathrm{~d}$ (Fig. 3).
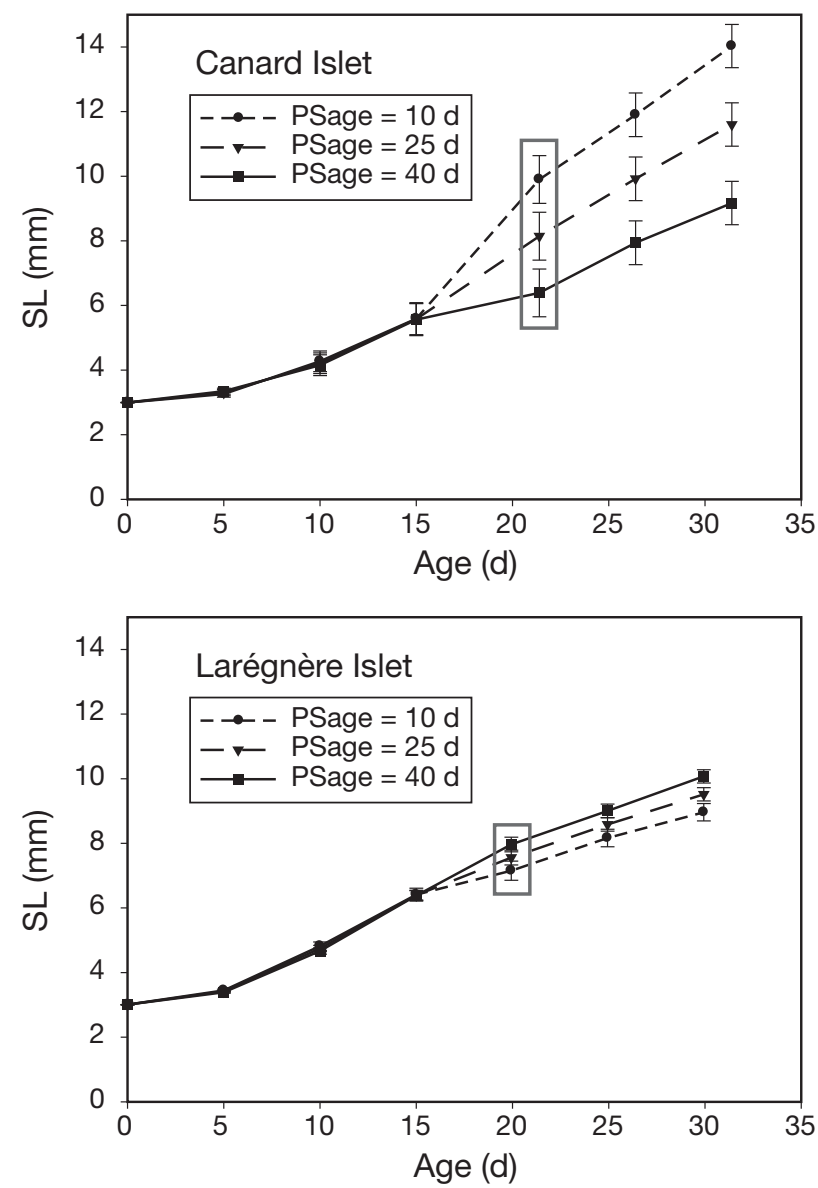

Fig. 3. Chromis viridis. Mean and SE (error bars) of size-at-age (standard length [SL], mm) predicted by repeated-measures generalised linear models for $C$. viridis at post-settlement ages (PSage) of 10, 25 and $40 \mathrm{~d}$ for Canard and Larégnère Islets. The settlement period is outlined (grey box) 


\section{DISCUSSION}

A statistical procedure was proposed to isolate growth performance back-calculated from otoliths from the potential effect of age-based factors. This procedure revealed that for 1 of the 3 studied species, Chromis viridis, growth performance was significantly agestructured. This corroborates results of other studies demonstrating the age-based structuring of growth performance, for instance through the effect of growthor size-selective mortality (Vigliola \& Meekan 2002, Takasuka et al. 2003) or differences in environmental conditions experienced by offspring, such as temporal variations in water temperature (Denit \& Sponaugle 2004). Therefore, the significant effect of postsettlement age on the growth performance of $C$. viridis may have originated from different causes. For example, if older $C$. viridis hatched and settled in warmer waters than younger ones, they could have experienced faster growth. Alternatively, size-selective mortality occurring after settlement could have progressively removed slower growers as cohort age increased (Denit \& Sponaugle 2004, Vigliola et al. 2007). An efficient way to disentangle the effect of post-settlement selective mortality from other age-structuring factors would be to perform longitudinal sampling of cohorts.

For Chromis viridis, the age structuring of growth performance differed significantly between islets. At Canard Islet, size-at-age trajectories were skewed toward those of slow-growing fish when the time spent in benthic habitats increased, but not at Larégnère Islet. Such spatial differences in the age-structuring of growth performance have already been observed in other studies and were explained, for instance, by spatial differences in environmental conditions encountered by fish at settlement (e.g. Rice et al. 1997). Differences in predator abundance between settlement sites have also been responsible for varying size-selective mortality among sites (Holmes \& McCormick 2006). Such selective mortality can sometimes be negative and thus preferentially remove large or fast-growing fish as post-settlement age increases. Indeed, smaller individuals may be able to lower their exposure to predators by sheltering more and consuming less food (Gagliano \& McCormick 2007b). For Lethrinus genivittatus and Siganus fuscescens however, no effect of post-settlement age on growth performance was observed. It can therefore be assumed that the spatial patterns in larval growth which we observed for these 2 species were not due to a confounding post-settlement age effect and that these patterns were really established at settlement.

Spatial differences appeared in the larval growth performance of Lethrinus genivittatus, with individuals from around Canard Islet experiencing slower larval growth than individuals from around Larégnère Islet. Spatial differences in larval growth performance have already been observed and were, for instance, attributed to differences in environmental conditions encountered by larvae around each islet (e.g. McCormick 1994). Other studies have showed that differences in maternal size, conditions and genetics are likely to influence egg size, larval size-at-hatching and growth performance (Vigliola \& Meekan 2002, Raventos \& Macpherson 2005). Spatially segregated populations with different maternal sizes, conditions and genetics can thus result in spatial differences in the larval growth of individuals caught as juveniles if self-recruitment is sufficiently high. For coral reef fish, a recent study actually suggests a higher self-recruitment rate that previously assumed, with up to $60 \%$ juveniles of Chaetodon vagabundus (Chaetodontidae) settling at a given site having been spawned at the same site (Almany et al. 2007).

No significant effect of post-settlement age was detected for Lethrinus genivittatus and Siganus fuscescens, but this does not guarantee the absence of growthselective mortality. Growth-selective mortality can actually be non-linear during the benthic phase and thus unrelated to post-settlement age. McCormick \& Hoey (2004) estimated that the mortality of the coral reef fish Pomacentrus amboinensis (Pomacentridae) was the highest $(25 \%)$ at settlement. They also suggested that mortality could have been selective toward larval growth performance early after settlement, and thereafter submitted to ontogenetic changes in direction or intensity. Indeed, several factors have been suggested to influence the timing and the intensity of growth-selective mortality after settlement, including temperature (Gagliano et al. 2007), maternal effects (Gagliano \& McCormick 2007a) and/or density (Vigliola et al. 2007).

Using post-settlement age as a covariate in RMGLMs therefore appeared to effectively disentangle growth performance from the effect of several potential age-based factors. In theory this procedure is extremely powerful even with small sample sizes. However, we believe that the present study should be considered as a pilot study and the technique should be repeated and tested on larger data sets including spatial and temporal replicates. This procedure should also be tested on artificial data sets, simulating the effect of different types of age-based factors, in order to examine the potential of the method to detect the respective effect of each factor on growth performance.

\section{CONCLUSIONS}

The statistical procedure used in the present study was able to isolate the effect of growth performance in the age-based structuring of populations and species, 
despite relatively small sample sizes. For one species, this procedure suggested that post-settlement growth was age-structured. The present study should thus be considered as a pilot study to isolate the growth performance in the age-structuring of populations. The proposed procedure should be repeated using large, longitudinally sampled data sets, to determine the respective roles of growth-selective mortality and environmental effects in the age-structuring of populations for different species. As indicated by Cowen \& Sponaugle (1997), the consideration of multiple species within and among families, from spawning to settlement and beyond, is necessary to infer meaningful hypotheses about early life history strategies and recruitment success. Further investigations are needed to assess the consistency of spatial patterns in growth performance, and to identify the factors responsible for these patterns. Such investigations are crucial, since growth and survival are 2 indicators of the quality of essential fish habitats (Beck et al. 2001) that primarily contribute to the replenishment of adult fish populations.

Acknowledgements. This project was funded by IRD, Programme d'Evaluation des Ressources Marines de la Zone Economique Exclusive de Nouvelle-Calédonie (ZoNéCo), Ministère de l'Outre-Mer and Programme National d'Environnement Côtier (PNEC). The preparation and interpretation of the otoliths was aided by the use of a microscope made available by a grant from the French Regional Initiative for the Protection and Management of Coral Reefs in the Pacific (CRISP). We thank G. Mou-Tham for his assistance in the field, and J. Baly and A. Grüss helped with otolith extraction and preparation. All methods employed in this study comply with the current laws and regulations in New Caledonia.

\section{LITERATURE CITED}

Almany GR, Berumen ML, Thorrold SR, Planes S, Jones GP (2007) Local replenishment of coral reef fish populations in a marine reserve. Science 316:742-744

Andréfouët S, Torres-Pulliza D (2004) Atlas des récifs coralliens de Nouvelle-Calédonie. IFRECOR Nouvelle-Calédonie, Nouméa

Beck MW, Heck KL, Able K, Childers DL and others (2001) The identification, conservation and management of estuarine and marine nurseries for fish and invertebrates. Bioscience 51:633-641

Campana SE (1990) How reliable are growth back-calculations based on otoliths? Can J Fish Aquat Sci 47:2219-2227

Cornell JE, Young DM, Deaman SL, Kirk RE (1992) Power comparisons of eight tests for sphericity in repeated measures designs. J Educ Stat 17:233-249

Cowan JH, Rose KA, Houde ED (1997) Size-based foraging success and vulnerability to predation: selection of survivors in individual-based models of larval fish populations. In: Chambers RC, Trippel EA (eds) Early life history and recruitment in fish populations. Chapman \& Hall, London, p 357-386

Cowen RK, Sponaugle S (1997) Relationships between early life history traits and recruitment among coral reef fishes. In: Chambers RC, Trippel EA (eds) Early life history and recruitment in fish populations. Chapman \& Hall, London, p 423-449

Dahlgren CP, Kellison GT, Adams AJ, Gillanders BM and others (2006) Marine nurseries and effective juvenile habitats: concepts and applications. Mar Ecol Prog Ser 312: 291-295

> Denit K, Sponaugle S (2004) Growth variation, settlement, and spawning of gray snapper across a latitudinal gradient. Trans Am Fish Soc 133:1339-1355

- Doherty PJ, Dufour V, Galzin R, Hixon MA, Meekan MG, Planes $\mathrm{S}$ (2004) High mortality during settlement is a population bottleneck for a tropical surgeonfish. Ecology 85: 2422-2428

Froese R, Pauly D (eds) (2008) FishBase. www.fishbase.org

Gagliano M, McCormick MI (2007a) Maternal condition influences phenotypic selection on offspring. J Anim Ecol 76: $174-182$

Gagliano M, McCormick MI (2007b) Compensating in the wild: Is flexible growth the key to early juvenile survival? Oikos 116:111-120

Gagliano M, McCormick MI, Meekan MG (2007) Temperature-induced shifts in selective pressure at a critical developmental transition. Oecologia 152:219-225

Holmes TH, McCormick MI (2006) Location influences sizeselective predation on newly settled reef fish. Mar Ecol Prog Ser 317:203-209

Houde ED (1987) Fish early life dynamics and recruitment variability. Am Fish Soc Symp 22:17-29

Jones GP, McCormick MI (2002) Numerical and energetic processes in the ecology of coral reef fishes. In: Sale PF (ed) Coral reef fishes: dynamics and diversity in a complex ecosystem. Academic Press, London, p 221-238

Leis JM (1991) The pelagic stage of reef fishes: the larval biology of coral reef fishes. In: Sale PF (ed) The ecology of fishes on coral reefs. Academic Press, San Diego, CA, p 183-230

Leis JM, Carson-Ewart BM (2001) The larvae of Indo-Pacific coastal fishes: an identification guide to marine fish larvae. Brill, Leiden

McCormick MI (1994) Variability in age and size at settlement of the tropical goatfish Upeneus tragula (Mullidae) in the northern Great Barrier Reef lagoon. Mar Ecol Prog Ser 103: $1-15$

- McCormick MI, Hoey AS (2004) Larval growth history determines juvenile growth and survival in a tropical marine fish. Oikos 106:225-242

Meekan MG, Fortier L (1996) Selection for fast growth during the larval life of Atlantic cod Gadus morhua on the Scotian Shelf. Mar Ecol Prog Ser 137:25-37

Pinazo C, Bujan S, Douillet P, Fichez R, Grenz C, Maurin A (2004) Impact of wind and freshwater inputs on phytoplankton biomass in the coral reef lagoon of New Caledonia during the summer cyclonic period: a coupled threedimensional biogeochemical modeling approach. Coral Reefs 23:281-296

Pitcher CR (1988) Validation of a technique for reconstructing daily patterns in the recruitment of coral-reef damselfish. Coral Reefs 7:105-111

Randall JE (2005) Reef and shore fishes of the South Pacific: New Caledonia to Tahiti and the Pitcairn Islands. University of Hawaii, Honolulu

Randall JE, Allen GR, Steene RC (1990) Fishes of the Great Barrier Reef and Coral Sea. Crawford House, Belair, South Australia

Raventos N, Macpherson E (2005) Effect of pelagic larval 
growth and size-at-hatching on post-settlement survivorship in two temperate labrid fish of the genus Symphodus. Mar Ecol Prog Ser 285:205-211

Rice JA, Crowder LB, Marschall EA (1997) Predation on juvenile fishes: dynamic interactions between size structured predators and prey. In: Chambers RC, Trippel EA (eds) Early life history and recruitment in fish populations. Chapman \& Hall, London, p 333-356

Robert D, Castonguay M, Fortier L (2007) Early growth and recruitment in Atlantic mackerel Scomber scombrus: discriminating the effects of fast growth and selection for fast growth. Mar Ecol Prog Ser 337:209-219

Sakamoto Y, Ishiguro M, Kitagawa G (1986) Akaike Information Criteria statistics. D. Reidel Publishing Company, Dordrecht/Tokyo

Searcy SP, Sponaugle S (2001) Selective mortality during the larval-juvenile transition in two coral reef fishes. Ecology 82:2452-2470

Takasuka A, Aoki I, Mitani I (2003) Evidence of growth-selective predation on larval Japanese anchovy Engraulis japonicus in Sagami Bay. Mar Ecol Prog Ser 252:223-238

Vigliola L, Meekan MG (2002) Size at hatching and planktonic growth determine post-settlement survivorship of a coral reef fish. Oecologia 131:89-93

Vigliola L, Meekan MG (in press) The back-calculation of fish growth from otoliths. In: Green BS, Begg GA, Carlos G,

Editorial responsibility: Paul Sammarco,

Chauvin, Louisiana, USA
Mapstone BM (eds). Tropical fish otoliths: information for assessment, management and ecology. Springer, New York

> Vigliola L, Harmelin-Vivien M, Meekan MG (2000) Comparison of techniques of back-calculation of growth and settlement marks from the otoliths of three species of Diplodus from the Mediterranean Sea. Can J Fish Aquat Sci 57: 1291-1299

Vigliola L, Doherty PJ, Meekan MG, Drown DM, Jones ME, Barber PH (2007) Genetic identity determines risk of postsettlement mortality of a marine fish. Ecology 88: 1263-1277

Wilson GG (1998) A description of the early juvenile colour patterns of 11 Lethrinus species (Pisces: Lethrinidae) from the Great Barrier Reef, Australia. Rec Aust Mus 50:55-83

Wilson DT, McCormick MI (1999) Microstructure of settlement-marks in the otoliths of tropical reef fishes. Mar Biol 134:29-41

Wilson JA, Vigliola L, Meekan MG (2008) The back-calculation of size and growth from otoliths: validation and comparison of models at an individual level. J Exp Mar Biol Ecol 368:9-21

Woodland DJ (1990) Revision of the fish family Siganidae with description of two new species and comments on distribution and biology. Indo Pacific Fishes 19, Bernice Pauahi Bishop Museum, Honolulu, HI

Submitted: May 5, 2008, Accepted: April 23, 2009

Proofs received from author(s): June 11, 2009 